\title{
Effects of Extenders and Cryoprotectants on Cryopreservation of Duck Semen
}

\author{
Atilla Taşkın $^{1}$, Fatma Ergün ${ }^{2}$, Ufuk Karadavut ${ }^{1}$, Demirel Ergün ${ }^{1}$ \\ ${ }^{1}$ Department of Animal Science, Faculty of Agriculture, Kirsehir Ahi Evran University, 40100 Kirsehir, Turkey \\ ${ }^{2}$ Faculty of Health Science, Kirsehir Ahi Evran University, 40100 Kirsehir, Turkey
}

*Corresponding author

\begin{tabular}{|c|c|}
\hline ARTICLE INFO & A B S T R A C T \\
\hline $\begin{array}{l}\text { Keywords: } \\
\text { Peking Duck } \\
\text { Semen } \\
\text { Cryopreservation } \\
\text { Vitality } \\
\text { Motility }\end{array}$ & 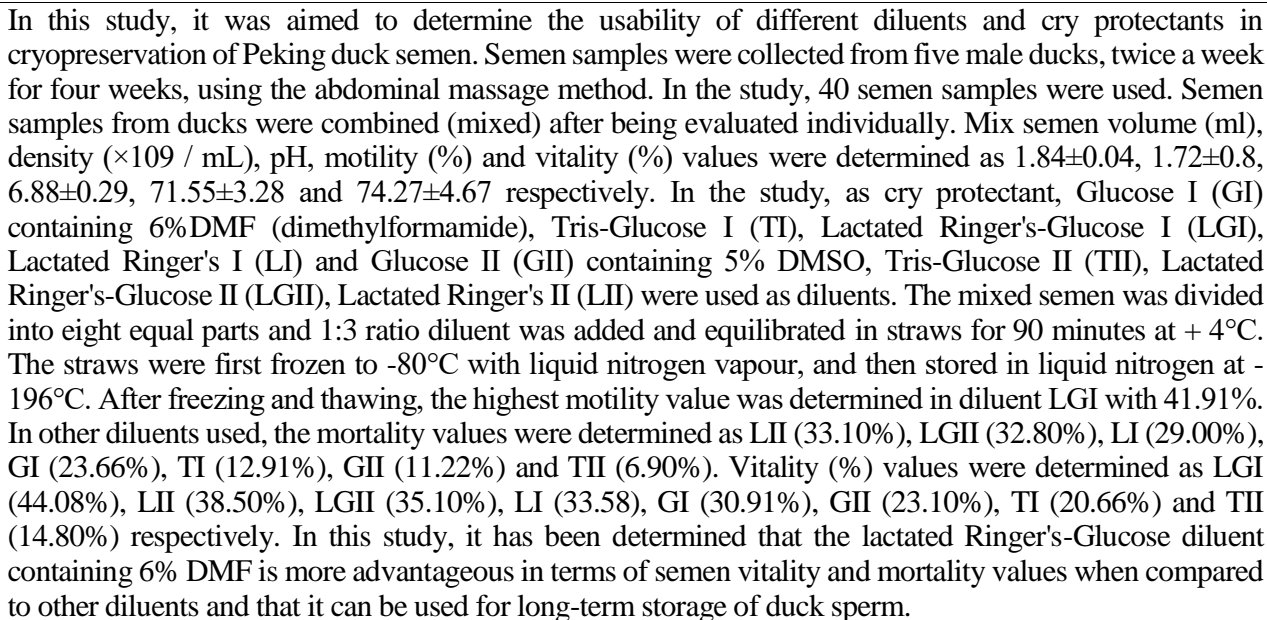 \\
\hline
\end{tabular}

Türk Tarım - Gıda Bilim ve Teknoloji Dergisi, 8(9): 1965-1970, 2020

\section{Ördek Spermi Kriyoprezervasyonunda Kriyoprotektanların ve Sulandırıciların Etkileri}

\begin{tabular}{|c|c|}
\hline M A K A L E B İ L G İ S İ & $\ddot{O} \mathrm{Z}$ \\
\hline $\begin{array}{l}\text { Anahtar Kelimeler: } \\
\text { Pekin Ördeği } \\
\text { Semen } \\
\text { Kriyoprezervasyon } \\
\text { Vitalite } \\
\text { Motilite }\end{array}$ & 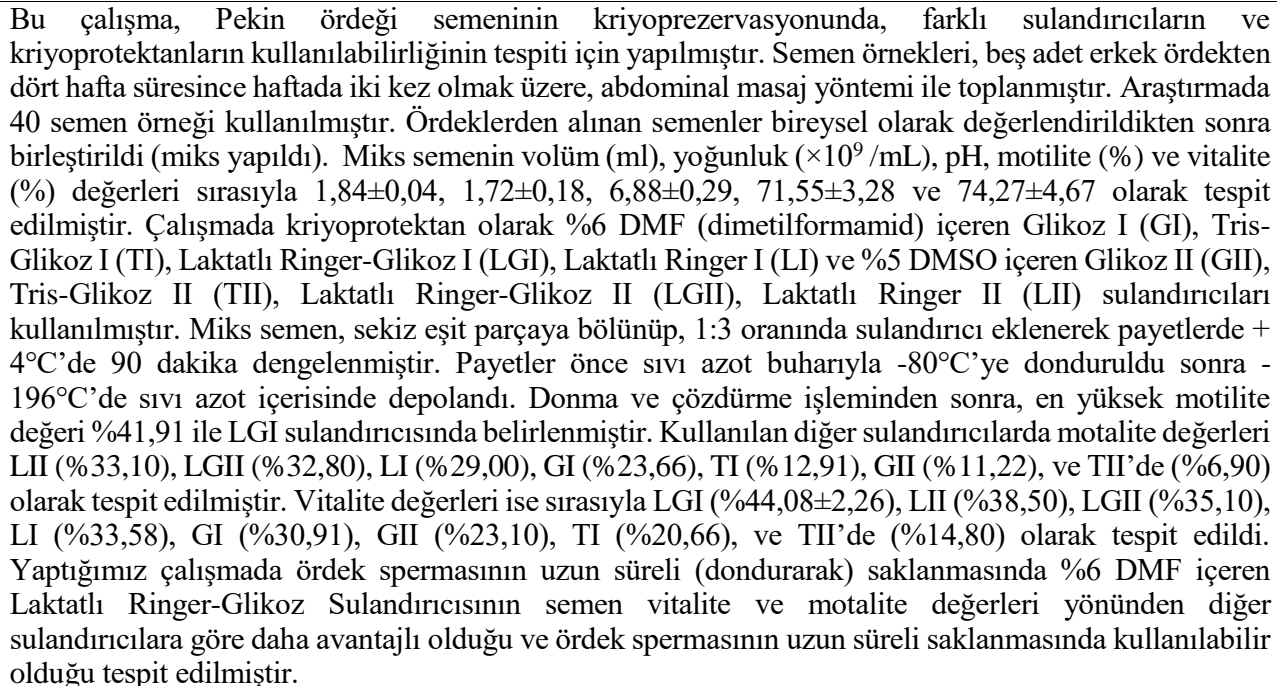 \\
\hline
\end{tabular}




\section{Introduction}

In terms of breeding, poultry constitutes a large part of the world's animal assets (FAOSTAT, 2018). However, many factors such as global warming, environmental pollution, outbreaks and unconscious hunting in the natural environment of these birds threaten many bird species (Özkazanç and Özay, 2019). This situation makes the conservation of genetic resources necessary.

Totipalmate feet ducks from the Anatinae subfamily have an important place in the bird population. As the ducks live wild on earth, dozens of their species are bred as pets. Studies on ducks are very important as the data obtained from these studies can be used for wildlife conservation as well as duck breeding.

From this point of view, semen cryopreservation, which expresses the reduction of biological activity of spermatozoa at low temperatures and their future use, is the most practical method for long-term storage and preservation of genetic material in poultry species (Blesbois et al., 2005). In addition, semen cryopreservation is an important tool to protect genetic diversity in terms of epidemic diseases (Blesbois et al., 2007). The purpose of semen cryopreservation is storage of the genetic material to be used in reproduction for a long time without being damaged by freezing process (Tunal1, 2014). In addition, semen cryopreservation is the most common method used by organizations established in order to provide ex situ protection of endangered poultry species and to prevent extinction caused by epidemic diseases (Blesbois, 2011; Danchin-Burge, 2005; Woelders et al., 2006).

Intracellular energy reserves of poultry spermatozoa are very low. For this reason, specially prepared diluents and cryoprotectants are used in cryopreservation in order to meet the energy and metabolite needs of spermatozoa in vitro and to prevent crystallization during cryopreservation (Mc Indoe and Lake, 1973; Sexton, 1974). The cryoprotectants used should have a low molecular weight and should be used by adding diluents in certain proportions. In addition, when using diluents and cryoprotectants, the cell must be incubated in order to stabilize intracellularly (Long, 2006; Blesbois and Brillard, 2007).

The most ideal medium in cryopreservation process is liquid nitrogen at $-196^{\circ} \mathrm{C}$. In such an environment, the temporal difference in storage time is eliminated (Tarvis, 2013). A successful freezing process takes place by rapid diffusion of cryoprotectants and water through the membrane (Dobrinsky, 2002). Poultry spermatozoa have low resistance to crystallization. Therefore, it is necessary to freeze spermatozoa at a slow speed to protect them from heat transitions (Iaffaldano et al., 2016).

Due to the low density of bird semen in the thawing phase of the cryopreservation process, spermatozoa are more susceptible to freezing/thawing than mammalian semen (Hammerstedt and Graham, 1992). In addition, changes in density and phase occur during freeze/thaw applications. Difference in density causes fluid loss in spermatozoa (Meryman et al., 1977), but this loss should be at a tolerable level. Otherwise, spermatozoa die due to maximum fluid loss. Depending on the phase change in the environment, changes in spermatozoa enzyme activities are observed and as a result, the viability rate of spermatozoa decreases (cryoinjury) (Bucak and Tekin, 2007).
In literature studies, it is stated that Glycerin (glycerol), DMSO (dimethylsulfoxide), DMA (dimethylacetamide), DMF (dimethylformamide) are used to freeze duck sperm, but further research is needed to minimize their negative effects and to increase fertilization capacities of spermatozoa (Setioko et al., 2002; Oguntunji et al., 2019; Han et al., 2005). In the study 6\% DMF used as cryoprotectant was used in semen cryopreservation of many poultry animals (Han et al., 2005; Lukaszewicz E. 2001; Kowalczyk and Łukaszewicz, 2015).

In this study, in long-term storage of duck sperm with cryopreservation, the usability of $6 \%$ DMF and 5\% DMSO cryoprotectants, and of glucose (G), Tris-Glucose (T), Lactated Ringer's-Glucose (LG), Lactated Ringer's (L) diluents were investigated

\section{Material and Method}

\section{Animal Material}

In this study, five 52-week-old male Peking ducks (Anas platyrhynchos domesticus), were used. Ducks were not restricted with food and water and they were fed with bait as ad libitum (18\% crude protein and $2300 \mathrm{kcal}$ $\mathrm{ME} / \mathrm{kg}$ ). Natural photoperiod was applied in March and April. Ducks were only prevented from reaching feed and water 12 hours before the semen was collected to prevent fecal contamination. This study was conducted with the permission (27.01.2016/1/10) of Ahi Evran University Animal Experiments Local Ethics Committee.

\section{Nativ Semen}

Collection; Initially, the ducks were made to get accustomed to giving sperm for two weeks. Abdominal massage method was used to collect semen from ducks (Burrows and Ouinn, 1937). Semen collection process was carried out in the early hours of the morning with the aid of wide-mouthed glass tubes heated to $+37.5^{\circ} \mathrm{C}$ and sterilized. Necessary measures were taken against cold shock and contaminations. This process continued for four weeks (twice a week, 8 samples from a duck, from 5 ducks 40 samples in total).

Macroscopic Inspection: Collected semen were kept at $+37.5^{\circ} \mathrm{C}$ until reconstitution. Semen collected and liquefied before combining were observed separately and care was taken to avoid contamination with feces and blood. $0.01 \mathrm{~mL}$ precision injectors (Ayset 70570) were used to determine the amount of semen taken from ducks at once in $\mathrm{mL}$. The collected semen was then mixed.

\section{Mix Semen}

Spermatozoa Density $(\mathrm{ml})$ : It was determined using the hemocytometric method and expressed as $x 10^{9} \mathrm{sp} / \mathrm{ml}$. For this purpose, $0.01 \mathrm{ml}$ of sperm was diluted 1/500 with $5 \mathrm{ml}$ of Hayem solution and put into Thoma slide. Sperm counts were performed in 5 large squares in each of the two counting sites on the Thoma slide, and 10 large squares in total. From the values found, the density was calculated with the help of the hemocytometric count equation and expressed as $\times 10^{9} \mathrm{sp} / \mathrm{ml}$. 


$$
\text { Density }(\mu \mathrm{l})=\frac{\mathrm{NSC}}{\mathrm{LSA} \times \mathrm{LSH} \times \mathrm{RR}}
$$

NCS $=$ Number of Spermatozoa Counted

LSA $=$ Large Square Area

LSH $=$ Large Square Height

$\mathrm{RR}=$ Reconstitution Rate

$p H$ Value: The $\mathrm{pH}$ value of the mixed semen that prepared to eliminate individual differences was determined with the help of $\mathrm{pH} \mathrm{0-14} \mathrm{Universal} \mathrm{indicator}$ and expressed as a numerical value (MColorpHast).

Motility (\%): It was performed at x400 magnification using a phase-contrast microscope (Leica DM750) with a heating table and expressed as \%. For this, $5 \mu 1$ semen was taken on the slide which was heated at $+37.5^{\circ} \mathrm{C}$ and the coverslip was closed at the same temperature. The preparation was placed on a heating plate (Type $\mathrm{D}$, Leica Mats) preheated to $+37.5^{\circ} \mathrm{C}$ and examined by two observers in at least 3 different microscope fields and expressed as \%. In the examination of the mixed semen, it was diluted 1:1 ratio with physiological serum (PS) in order to better observe motility. In the repeated measurements, no diluent was added.

Vitality (\%): The basis of Eosin nigrosin sperm staining is based on the fact that it takes the dye into the cytoplasm and the sperm appears to be painted due to the deterioration of the membrane structure of dead spermatozoa. $5 \mu 1$ of semen was mixed with $10 \mu \mathrm{l}$ of $1 \%$ Eosin-Y in a tube. After 30 seconds, $15 \mu \mathrm{l}$ of $10 \%$ Nigrosin was added and mixed. $1 \mu 1$ of the mixture was taken and spread on the slide. It was left to dry at room temperature $\left(21^{\circ} \mathrm{C}\right)$. Then, 200 sperms were examined under a microscope. Dead spermatozoa were observed in red and purple, while living spermatozoa were observed in white and colorless (Lemoine et al., 2011) and expressed as\%.

\section{Diluents}

The diluents used in the study were prepared as follows; Glucose I Diluent (GI): Glucose (0.37M (D (+) Glucose-monohydrate), $370 \mathrm{mOsm} / \mathrm{L}$ ) containing $6 \%$ (v/v) DMF cryoprotectant

Glucose II Diluent (GII): Glucose (0.37M (D (+) Glucose-monohydrate), $370 \mathrm{mOsm} / \mathrm{L}$ ) containing $5 \%$ (v/v) DMF cryoprotectant

Tris-Glucose I Diluent (TI): Tris-Glucose (30mM / L Tris (hydroxymethyl) -aminomethane $+300 \mathrm{mM} / \mathrm{L} \mathrm{D} \mathrm{(+)}$ - Glucosemonohydrate) containing 6\% (v/v) DMF cryoprotectant

Tris-Glucose II Diluent (TII): Tris-Glucose (30mM / L Tris (hydroxymethyl) -aminomethane $+300 \mathrm{mM} / \mathrm{L}$ D (+)
- Glucosemonohydrate) containing $5 \%(\mathrm{v} / \mathrm{v})$ DMF cryoprotectant

Lactated Ringer's I Diluent (LI): LG containing 6\% (v/v) DMF cryoprotectant ( 0.03 g potassium chloride, 0.02 $\mathrm{g}$ calcium chloride, $0.31 \mathrm{~g}$ sodium lactate, $0.60 \mathrm{~g}$ sodium chloride, $100 \mathrm{ml}$ for distilled water)

Lactated Ringer's II Diluent (LII): LG containing 5\% (v/v) DMF cryoprotectant ( 0.03 g potassium chloride, 0.02 $\mathrm{g}$ calcium chloride, $0.31 \mathrm{~g}$ sodium lactate, $0.60 \mathrm{~g}$ sodium chloride, $100 \mathrm{ml}$ for distilled water)

Lactated Ringer's-Glucose I Diluent (LGI): LRGlucose $(0.03 \mathrm{~g}$ potassium chloride, $0.02 \mathrm{~g}$ calcium chloride, $0.31 \mathrm{~g}$ sodium lactate, $0.60 \mathrm{~g}$ sodium, containing 6\% (v/v) DMF cryoprotectant. chloride, 1 g D (+) Glucose-monohydrate, for $100 \mathrm{ml}$ of distilled water)

Lactated Ringer's-Glucose II Diluent (LGII): LRGlucose $(0.03 \mathrm{~g}$ potassium chloride, $0.02 \mathrm{~g}$ calcium chloride, $0.31 \mathrm{~g}$ sodium lactate, $0.60 \mathrm{~g}$ sodium, containing 6\% (v/v) DMF cryoprotectant. chloride, 1 g D (+) Glucose-monohydrate, for $100 \mathrm{ml}$ of distilled water)

Serum Physiological Diluent (SP): 9\% IsotonicSodium Chloride, 100ml: Sodium Chloride: $0.9 \mathrm{~g}$, Water for Ejection k.m: 100ml, Amount of Electrolyte per liter $\left.\mathrm{Na}^{+} / 154 \mathrm{mEq} / \mathrm{c}\right\urcorner-154 \mathrm{mEq}$, Total Osmolar Concentration: $308 \mathrm{mOsm} / \mathrm{L}$.

\section{Freezing Procedure}

Dilution and equilibration of semen:

$0.20 \mathrm{ml}$ of the mixed semen whose spermatological properties were determined were placed in graded sterile plastic tubes with mouths covered to form 8 groups. They were added with 1/3 ratio (1part semen, 3 parts diluent) from GI, GII, TI, TII, LI, LII, LGI and LGII diluents. During this process, care was taken to ensure that the diluents and the sperm were at the same temperature $\left(+37.5^{\circ} \mathrm{C}\right)$, and the diluent was gradually added to the sperm. After diluting, sperms were evaluated for vitality and motality and then recorded. They were later drawn to straws (Min. $0.25 \mathrm{ml}$ ) and equilibrated for 90 minutes at $+5^{\circ} \mathrm{C}$. After equilibrating, sperms were evaluated and recorded for vitality and mortality.

Freezing and thawing of sperm

Sperms in straws were frozen in liquid nitrogen vapor at $-80^{\circ} \mathrm{C}$ for five minutes. Frozen straws were stored at $196^{\circ} \mathrm{C}$ in liquid nitrogen. Straws stored in liquid nitrogen were removed and thawing was done by keeping them in a water bath for 5 seconds at $+37^{\circ} \mathrm{C}$. After freezing/thawing, sperms were evaluated for vitality and mortality and the data obtained were recorded (Sexton, 1981) (Table 1).

Table 1. Sperm freezing/thawing procedure

\begin{tabular}{|c|c|c|}
\hline Step & Process & Procedure \\
\hline 1 & Dilution of semen and grouping & $\begin{array}{l}\text { Addition of diluents }(1 / 3 \text { rate) containing } 6 \% \text { DMF, 5\% DMSO } \\
\text { cryoprotectant and forming eight groups }\end{array}$ \\
\hline 2 & Packaging of sperms & Filling the sperms into straws \\
\hline 3 & Sperm equilibration & 90 minutes at $+5^{\circ} \mathrm{C}$ \\
\hline 4 & Freezing of sperms & Five minutes in liquid nitrogen vapor at $-80^{\circ} \mathrm{C}$ \\
\hline 5 & Storage of sperms & 24 hours in liquid nitrogen at $-196^{\circ} \mathrm{C}$ \\
\hline 6 & Thawing of sperms & 5 seconds in water bath at $+37^{\circ} \mathrm{C}$ \\
\hline
\end{tabular}




\section{Statistical Analysis}

The data obtained in the study were analyzed using SPSS 15.0 statistical software programs. Significance test was made according to $\mathrm{P}<0.05$ and the results were evaluated accordingly. In addition, variance analysis was applied to determine whether there was any difference between the data obtained within the groups in the study. DUNCAN test, which is one of the multiple comparison tests, was used for the features that are important as a result of variance analysis.

\section{Results and Discussion}

One of the main determinants of male reproductive potential is semen quality. Semen quality is very important for reproductive success. It has been reported that physiological and environmental factors such as race, age, breeding season, lighting program, management system of males, climatic conditions, feeding, health status, ejaculate collection technique and frequency are effective on the daily amount of ejaculate to be taken from the ducks (Siudzińska and Łukaszewicz, 2008; Kelso et al., 1996; Chemineau et al., 2007; Jerysz and Łukaszewicz, 2013; Kowalczyk et al., 2012; Kowalczyk and Łukaszewicz, 2015; Kasai and Izumo, 2001; Ghonim et al., 2009).

In this study, the average amount of ejaculate taken daily from the ducks was determined as $0.36 \pm 0.04$ (Table 2). In their study on Peking ducks, Kamar (1962) and Wagner and Pingel (1995) reported daily ejaculate amount as $0.32 \mathrm{ml}$ and $0.37 \mathrm{ml}$, respectively. These values are similar to the value we have found. Also, in similar studies, ejaculate amounts were determined as an average of $0.74 \pm$ $0.07 \mathrm{ml}$ (Nahak et al., 2015), $0.16 \pm 0.04 \mathrm{ml}$ (Cyriac et al., 2013), $0.65 \pm 0.04 \mathrm{ml}$ (Mossa, 2006) and $0.23 \pm 0.02 \mathrm{ml}$ (Zawadzka et al., 2015).

The $\mathrm{pH}$ value of the mixed semen, which was combined after collecting daily from the ducks, was determined to be $6.88 \pm 0.29$ (Table 3 ). This value is similar to the $\mathrm{pH}$ value of $6.90 \pm 0.44$ found in J. Zawadzka et al., (2015) in their study on ducks. Similarly, the $\mathrm{pH}$ value was reported as $7.48 \pm 0.06$ in a study conducted on Beijing ducks (Cyriac et al., 2013). In addition, it has been reported that semen $\mathrm{pH}$ value affects spermatozoa motality, the alkaline medium in some bird species increases semen mobility (Holm and Wishart, 1998) and semen collection technique has an effect on pH (Mossa, 2006).

The density value of mixed semen was determined as $1.72 \pm 0.18 \times 10^{9} / \mathrm{ml}$ (Table 3 ). In studies on ducks, the density value was reported as $1.5-8.0 \times 10^{9} / \mathrm{ml}$ (Surai and Wishart, 1996), 3.03 $\times 10^{9} / \mathrm{ml}$ (Cyriac et al., 2013), and $0.84-1.3 \times 10^{9} / \mathrm{ml}$ (Nahak et al., 2015) respectively. The value of $1.72 \pm 0.18 \times 10^{9} / \mathrm{ml}$ we have found in this study is within physiological limits and is similar to these values. Collection technique and frequency of semen intake affect the semen density. In the study conducted on ducks, the semen density value was determined as $6.5 \times 10^{9} / \mathrm{ml}$ by electro ejaculate method and $3.2 \times 10^{9} / \mathrm{ml}$ by abdominal massage method (Kasai and Izumo, 2001). In a similar study, the highest semen density value was obtained with a frequency of intake twice a week (Ghonim et al., 2009). In addition, semen density has been reported to differ among duck species (Mossa, 2006).
In this study, eosin nigrosin sperm staining technique was used to determine the vitality (\%) of mixed semen. Dead spermatozoa were seen as red or purple in colour whereas live spermatozoa were white or colorless. (Figure 1).

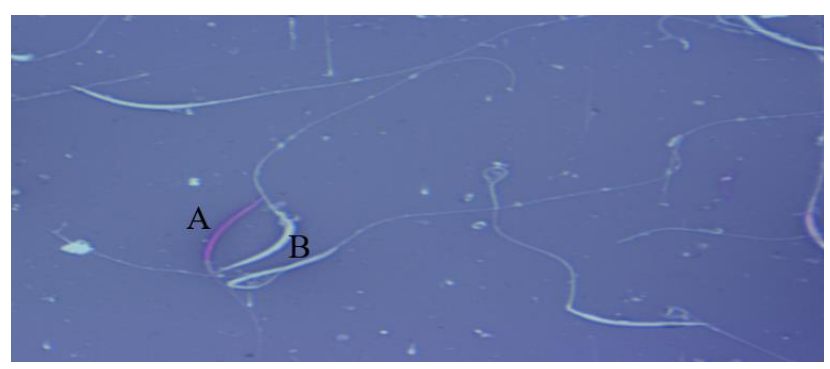

Figure 1. Microscopic view of spermatozoa (A: Dead spermatozoa, B: Live spermatozoa)

Table 2. Average amount of semen taken daily from ducks

\begin{tabular}{l|cc}
\hline Duck Number & Number $(\mathrm{n})$ & Amount $(\mathrm{ml}) \mathrm{X} \pm \mathrm{Sx}$ \\
\hline 1 & 8 & $0.36 \pm 0.03$ \\
2 & 8 & $0.38 \pm 0.26$ \\
3 & 8 & $0.37 \pm 0.03$ \\
4 & 8 & $0.34 \pm 0.05$ \\
5 & 8 & $0.37 \pm 0.03$ \\
\hline Total & 40 & $0.36 \pm 0.04$ \\
\hline
\end{tabular}

Table 3. Spermatological value table of mixed semen

\begin{tabular}{l|c}
\hline \multicolumn{1}{c}{ Spermological characteristic } & $(\overline{\mathrm{X}} \pm \mathrm{Sx})$ \\
\hline Daily Amount $(\mathrm{ml})$ & $1.84 \pm 0.04$ \\
$\mathrm{pH}$ & $6.88 \pm 0.29$ \\
Density $\left(\mathrm{x} 10^{9} / \mathrm{ml}\right)$ & $1.72 \pm 0.18$ \\
Motility (\%) & $71.55 \pm 3.28$ \\
Vitality (\%) & $74.27 \pm 4.67$ \\
\hline
\end{tabular}

Table 4. Vitality change table $(\bar{X} \pm S x)(\mathrm{P}<0.05)$

\begin{tabular}{l|lll}
\hline Diluent & \multicolumn{1}{c}{ VED } & VME & VF \\
\hline GI & $59.83 \pm 4.86^{\mathrm{b}}$ & $57.41 \pm 7.96^{\mathrm{ab}}$ & $30.91 \pm 8.70^{\mathrm{c}}$ \\
GII & $53.00 \pm 3.10^{\mathrm{c}}$ & $40,40 \pm 3,89^{\mathrm{c}}$ & $23.10 \pm 2.40^{\mathrm{d}}$ \\
TI & $50.58 \pm 2.69^{\mathrm{cd}}$ & $44.08 \pm 4.11^{\mathrm{c}}$ & $20.66 \pm 4.47^{\mathrm{d}}$ \\
TII & $46.30 \pm 1.30^{\mathrm{d}}$ & $33.40 \pm 2.24^{\mathrm{d}}$ & $14.80 \pm 2.43^{\mathrm{e}}$ \\
LGI & $66.66 \pm 6.45^{\mathrm{a}}$ & $61.83 \pm 5.51^{\mathrm{a}}$ & $44.08 \pm 2.26^{\mathrm{a}}$ \\
LGII & $63.60 \pm 2.58^{\mathrm{ab}}$ & $54.20 \pm 4.43^{\mathrm{b}}$ & $35.10 \pm 2.70^{\mathrm{bc}}$ \\
LI & $65.91 \pm 5.84^{\mathrm{a}}$ & $59.66 \pm 4.87^{\mathrm{ab}}$ & $33.58 \pm 2.63^{\mathrm{bc}}$ \\
LII & $60.50 \pm 2.57^{\mathrm{b}}$ & $55.70 \pm 0.90^{\mathrm{ab}}$ & $38.50 \pm 1.93^{\mathrm{b}}$ \\
\hline
\end{tabular}

VED: \% Vitality value at the end of dilution, VME: \%Vitality value after 90 minutes of equilibration at $+5^{\circ} \mathrm{C}$, VF: \% Vitality value after freezing/thawing

Table 5. Motality change table $(\bar{X} \pm S x)(\mathrm{P}<0.05)$

\begin{tabular}{l|lll}
\hline Diluent & \multicolumn{1}{c}{ VED } & VME & VF \\
\hline GI & $56.58 \pm 4.15^{\mathrm{c}}$ & $42.25 \pm 2.42^{\mathrm{c}}$ & $23.66 \pm 3.23^{\mathrm{d}}$ \\
GII & $49.70 \pm 3.11^{\mathrm{d}}$ & $36.90 \pm 1.94^{\mathrm{d}}$ & $11.22 \pm 0.75^{\mathrm{e}}$ \\
TI & $47.83 \pm 2.78^{\mathrm{d}}$ & $34.41 \pm 1.46^{\mathrm{d}}$ & $12.91 \pm 1.15^{\mathrm{e}}$ \\
TII & $33.90 \pm 1.38^{\mathrm{e}}$ & $28.90 \pm 1.29^{\mathrm{e}}$ & $6.90 \pm 0.74^{\mathrm{f}}$ \\
LGI & $65.25 \pm 5.53^{\mathrm{a}}$ & $58.83 \pm 2.94^{\mathrm{a}}$ & $41.91 \pm 1.59^{\mathrm{a}}$ \\
LGII & $60.80 \pm 2.07^{\mathrm{abc}}$ & $51.70 \pm 3.56^{\mathrm{b}}$ & $32.80 \pm 2.25^{\mathrm{b}}$ \\
LI & $62.91 \pm 5.58^{\mathrm{ab}}$ & $56.58 \pm 2.70^{\mathrm{a}}$ & $29.00 \pm 1.41^{\mathrm{c}}$ \\
LII & $58.60 \pm 2.77^{\mathrm{bc}}$ & $53.30 \pm 3.09^{\mathrm{b}}$ & $33.10 \pm 1.19^{\mathrm{b}}$ \\
\hline
\end{tabular}

VED: \% Vitality value at the end of dilution, VME: \%Vitality value after 90 minutes of equilibration at $+5^{\circ} \mathrm{C}$, VF: $\%$ Vitality value after freezing/thawing 
Mix semen was found to have a motility value of $71.55 \% \pm 3.28$ and a vitality value of $74.27 \% \pm 4.67$ (Table $3)$. In a different study on ducks, motility value was reported as $72.85 \%$ and vitality value as $67.90 \%$ (Kontecka, 1992). Also, in a similar study, the motility value was reported as $61.1 \%$ (Kasai and Izumo, 2001). It was reported that the contaminants such as blood, feces and lymph fluid coming before or after the semen during semen removal adversely affect the motility and vitality values (Fujihara et al., 2001; Lake, 1983). In addition, a study on ducks reported that artificial vagina method based on natural mating behavior positively affects the motility and vitality values (Kasai and Izumo, 2001).

In groups formed with GI, GII, TI, TII, LGI, LGII, LI and LII diluents; vitality values were determined at the end of dilution, after 90 minutes of equilibration at $+5^{\circ} \mathrm{C}$ and after freezing-thawing (Table 4).

The differences between the groups in terms of vitality value at the end of dilution were found significant $(\mathrm{P}<0.05)$. Vitality value was determined as the highest $(66.66 \% \pm 6.45)$ in LGI diluent and the lowest $(46.30 \% \pm 1.30)$ in TII diluent. The vitality values of spermatozoa, which were equilibrated at $+5^{\circ} \mathrm{C}$ for 90 minutes (equilibration); LII, LI, GI and GII, TI diluents were similar among themselves, and the differences between other diluents were significant $(\mathrm{P}<0.05)$. The highest value was determined as $54.20 \% \pm 4.43$ in LGI diluent and the lowest value was $33.40 \% \pm 2.24$ in TII diluent. As for the value of vitality as a result of freezing/thawing; when forming a group with GII, TI and with LGII, LI, the differences between diluents were found to be significant $(\mathrm{P}<0.05)$, and the highest vitality value was seen as $44.08 \% \pm 2.26$ in LGI diluent while the lowest vitality value was found as $14.80 \% \pm 2.43$ in the TII diluent.

In groups formed with GI, GII, TI, TII, LGI, LGII, LI and LII diluents; motility values were determined, at the end of dilution, after 90 minutes of equilibration at $+5^{\circ} \mathrm{C}$ and after freezing/thawing (Table 5).

The differences between the groups in terms of motility values at the end of dilution were found to be significant at $\mathrm{P}<0.05$ and the highest motility value was determined as $65.25 \% \pm 5.53$ in LGI diluent and the lowest value was $33.90 \% \pm 1.38$ in TII diluent. As for the motility values of the groups equilibrated at $+5^{\circ} \mathrm{C}$ for 90 minutes (equilibration), LII and LGII, GII and TI, and LGI and LI diluents were similar among themselves, and the differences between other diluents were found to be significant $(\mathrm{P}<0.05)$. The highest value was $58.83 \% \pm 2.94$ in LGI diluent and the lowest motility value $28.90 \% \pm 1.29$ in TII diluent. After freezing/thawing process, while LGII and LII, and GII and TI diluents were grouped among themselves, the difference between other diluents was identified to be significant at $\mathrm{P}<0.05$. The highest motility value was $41.91 \% \pm 1.59$ in LGI diluent and the lowest motility value was $6.90 \% \pm 0.74$ in TII diluent.

When evaluated in diluents containing 5\% DMSO in terms of motility and vitality values as a result of freezing/ thawing, the highest motility and vitality values were detected as $33.10 \% \pm 1.19,38.50 \% \pm 1.93$ respectively in LII diluent and the lowest value $6.90 \% \pm 0.74,14.80 \% \pm 2.43$ in TII diluent. In a similar study on ducks, as a result of freezing / thawing using 7\% DMSO, the lowest vitality value was found as $21.75 \%$ and the highest as $32.45 \%$
(Setıoko et al., 2002). However, when the vitality and motility values found in studies using 5\% DMSO and the same diluents (Kuzlu and Taskin, 2017) on turkeys and 5\% DMSO on chickens were compared to the values found in this study, differences were observed. It is thought that these differences may have resulted from the chemical structure of DMSO, the change it made in the diluent used together, and the different stotoxic effect on different poultry spermatozoa (Sexton, 1982).

In the diluents containing 6\% DMF, when the motality and vitality values were analyzed after the freezing/thawing process, the highest motality and vitality values were identified as $41.91 \% \pm 1.59,44.08 \% \pm 2.26$ respectively in LGI diluent and the lowest values $12.91 \% \pm$ $1.15,20.66 \% \pm 4.47$ respectively in TI diluent. Similarly, in a study on ducks using diluents that contained $7 \% \mathrm{DMF}$, the vitality value was determined to be $32.86 \% / 34.92 \%$ as a result of the freezing/thawing (Setioko et al., 2002).

In a study conducted on turkeys with similar diluents, the highest vitality and motality value after freezing/thawing was determined in glucose diluent containing 5\% DMSO (Sexton, 1982). However, in this study, the highest value for motality and vitality was determined in Lactated Ringer's-Glucose diluent containing 6\% DMF. This reveals the importance of seeking different freezing diluents for different poultry species.

\section{Conclusion}

Semen cryopreservation is one of the most economical methods of moving gene resources from one region to another. It also provides the opportunity to obtain a large number of offspring from male breeder animals. The importance of the subject has been better understood recently and studies on this issue have increased. In this study that we made for the purpose of preserving duck semen for a long time, it was determined that the lactated Ringer's Ringer-Glucose Diluent containing 6\% DMF is more advantageous in terms of vitality and motility values and it can be used for long term storage of duck sperms. However, it is thought that more research is needed to reduce the negative effects of long-term storage of duck sperm by freezing.

\section{References}

Blesbois E, Brillard JP. 2007. Specific features of in vivo and in vitro sperm storage in birds. Animal, 1(10): 1472-1481.

Blesbois E, Grasseau I, Seigneurin F. 2005. Membrane fluidity and the ability to survive cryopreservation in domestic bird spermatozoa. Reproduction, 129: 371-378.

Blesbois E, Seigneurin F, Grasseau I, Limouzin C, Besnard J. 2007. Semen cryopreservation for ex situ management of genetic diversity in chicken: creation of the french avian cryobank. Poult Sci., 86: 555-564.

Blesbois E. 2011. Freezing Avian Semen. Avian Biology Research, 4: 44-50.

Bucak MN, Tekin N. 2007. Kriyoprotektanlar ve gamet hücrelerinin dondurulmasında kriyoprotektif etki, Ankara Uni. Vet Fak. Derg., 54: 67-72.

Burrows WH, Ouinn JP. 1937. The collection of spermatozoa from the domestic fowl and the turkey. Poultry Science, 16:19-24. 
Chemineau P, Malpaux B, Brillard JP, Fostier A. 2007. Seasonality of reproduction and production in farm fishes, birds and mammals. Animal, 1,419-432.

Cyriac S, Joseph L, Peethambaran PA, Narayanankutty K, Karthiayın K. 2013. Semen quality characteristics of White Pekin, Kuttanad (Anas platyrhynchos domesticus) and Muscovy (Cairina moschata momelanotus) drakes. Indian J. Anim. Sci., 83,595-599.

Danchin-Burge, C. 2005. Mise en place de cryo-collections patrimoniales de races d'animaux d'e'levage, Cas de la France et des autres pays europe'ens. Proc. 31st, Journee d'e'tude, Les Haras Nationaux, Arnac-Pompadour, France

Dobrinsky JR. 2002. Advancements in cryopreservation of domestic animal embryos. Theriogenology, 57(1) 285-302.

FAOSTAT, 2018. Tarım istatistikleri internet veritabanı. http://faostat.fao.org/., [10.02.2020].

Fujihara N, Xi YM, Zhang MJ. 2001. Genetic resource conservation in poultry reproduction. J. App. Anim. Res., 19,33-47.

Ghonim AIA, Awad AL, El-Sawy MA, Fatouh MH, Zenat AI. 2009. Effect of frequency of semen collection, dilution rate and insemination dose on semen characteristics and fertility of Domyati ducks. Egypt. Poult. Sci. J., 29,1023-1045.

Hammerstedt RH, Graham JK. 1992. Cryopreservation of poultry semen: The enigma of glycerol. Cryobiology, 29: 26-38.

Han XF, Niu ZY, Liu FZ, Yang CS. 2005. Effects of diluents, cryoprotectants, equilibration time and thawing temperature on cryopreservation of duck semen. International Journal of Poultry Science, 4(4): 197-201.

Holm L, Wishart GJ. 1998. The effect of pH on the motility of spermatozoa from chicken, turkey and quail. Anim. Reprod. Sci., 54,45-54.

Iaffaldano N, Di Iorio M, Manchisi A, Esposito S, Gibertoni PP. 2016. Effective freezing rate for semen cryopreservation in endangered Mediterranean brown trout (Salmo trutta macrostigma) inhabiting Biferno River (South Italy). Zygote, 24(5):668-675.

Jerysz A, Łukaszewicz E, 2013. Effect of dietary selenium and vitamin $\mathrm{E}$ on ganders' response to semen collection and ejaculate characteristics. Biol. Trace Elem. Res., 153,196204.

Kamar GAR. 1962. Semen characteristics of various breeds of drakes in the subtropics. J. Reprod. Fertil., 3,405-409.

Kasai K, Izumo A. 2001. Efficiency of artificial vagina method in semen collection from Osaka Drakes. J. App. Poult. Res., 10, 206-210.

Kelso KA, Ceroloni S, Noble RC, Sparks NH, Speakle BK. 1996. Lipid and antioxidant changes in semen of broiler fowl from 25 to 60 weeks of age. J. Reprod. Fertil., 106,201-206.

Kontecka H. 1992. Sperm quality changes in drakes during the reproductive season. Rocz. Nauk. Zoot., 1 (19),9-18.

Kowalczyk A, Łukaszewicz E, Rzońca Z. 2012. Successful preservation of capercaillie (Tetrao urogallus L.) semen in liquid and frozen states. Theriogenology, 77,899-907.

Kowalczyk A, Łukaszewicz E. 2015. Simple and effective methods of freezing capercaillie (Tetrao urogallus L.) semen. Plos One, 10 (1), 1-11.

Kuzlu M, Taskin A. 2017. The effect of different extenders on the sperm motility and viability of frozen turkey semen. Indian J. Anim. Res., 51(2),235-241.

Lake PE. 1983. The male in reproduction. In: Physiology and Biochemistry of the domestic fowl. Ed: B. K. Freeman. 5,161.
Lemoine M, Mignon-Grasteau S, Grasseau I, Magistrini M, Blesbois E. 2011. Ability of chicken spermatozoa to undergo acrosome reaction after liquid storage or cryopreservation. Theriogenology, 751: 122-130.

Long JA. 2006. Avian semen cryopreservation: what are the biological challenges? Poult. Sci., 85:232-236

Lukaszewicz E. 2001. DMF effects on frozen gandersemen. $\mathrm{Br}$ Poult Sci., 42(3): 308-14.

Mc Indoe WM, Lake PE. 1973. Proceedings: aspects of energy metabolism of avian spermatozoa. Journal of Reproduction and Fertility, 35: 592-593.

Meryman H, Williams RT, Douglas MSJ. 1977. Freezing injury from solution effects and its prevention by nature or artificial cryoprotection. Cryobiology, 14: 287-302.

Mossa RK. 2006. Characterization of Iraqi local drake ejaculate and effect of frequency of collection in sperm quality. Bas. J. Vet. Res., 5,146-152.

Nahak AK, Giri SC, Mohanty DN, Mishra PC, Dash SK. 2015. Effect of frequency of collection on seminal characteristics of White Pekin duck. Asian Pacific Journal of Reproduction, 4(1):70-73.

Oguntunji AO, Oladejo AO, Ayoola MO, Oriye LO, Egunjobi IM. 2019. Semen quality parameters of three duck genotypes in the humid tropics. Zhivotnovadni Nauki, 56(4), 50-58.

Özkazanç NK, Özay E. 2019. Göçmen kuşları tehdit eden faktörler. Bartın University International Journal of Natural and Applied Sciences, 2(1): 77-89.

Setıko AR, Situmorang P, Trıwulannıngsı E, Sugıartı Dan DT, Kusumanıngrum A. 2002. Pengaruh Krioprotektan dan Waktu Ekuilibrasi Terhadap Kualitas dan Fertilitas Spermatozoa Itik dan Entog. JITV, 7(4), 237-243.

Sexton TJ. 1974. Oxidative and glycolytic activity of chicken and turkey spermatozoa. Comparative Biochemistry and Physiology B, 48,59-65.

Sexton TJ. 1981. Development of a commercial method for freezing turkeys semen. 1. effect of prefreeze techniques on the fertility of processed unfrozen and frozen-thawed semen. Poult. Sci., 60:1567-1573.

Sexton TJ. 1982. Beltsville poultry semen extender. 6. Holding turkey semen for six hours at $15^{\circ} \mathrm{C}$. Poultry Science, 61,1202-1208.

Siudzińska A, Łukaszewicz E. 2008. Effect of semen extenders and storage time on sperm morphology of four chicken breeds. J. Appl. Poult. Res., 17,101-108.

Surai PF, Wishart GJ. 1996. Poultry artificial insemination technology in the countries of the former USSR. World Poult. Sci. J., 52(1):27-43.

Tarvis KM, 2013. New methods for cryopreserving rooster spermatozoa. Master's Thesis, Colorado State UniversityDepartment of Biomedical Sciences.

Tunalı G. 2014. Sperm kriyoprezervasyon teknikleri ve fertilizasyon başarısındaki rolü. Androloji Bülteni Dergisi, 16(57): 123-128.

Wagner A, Pingel H. 1995. Characteristics of semen of Muscovy and Pekin drakes. Proc. 10th Eur. Symp. Waterfowl, Halle, Germany, 286-290.

Woelders H, Zuidberg CA, Hiemstra SJ. 2006. Animal Genetic Resources Conservation in The Netherlands and Europe: Poultry Perspective. Poultry Science 85:216-222.

Zawadzka J, Łukaszewicz E, Kowalczyk A. 2015. Comparative semen analysis of two Polish duck strains from a conservation programme. Europ. Poult. Sci., 79,1-9. 